\title{
Transformations in Real Estate Investments During Pandemic
}

\author{
Lam An Yin Andrew ${ }^{1}$ \\ ${ }^{I}$ Department of Economics, The Hong Kong University of Science and Technology, Hong Kong, China \\ *Corresponding author. Email: lamanyin@gmail.com
}

\begin{abstract}
COVID-19 drowns the real estate industry severely as the border restrictions hindered business and consumption activities like traveling. Thus, this report aims to investigate how the industry transformations could resist the industry recession and whether there are investment opportunities in the real estate industry. This report would focus on the current problems and the emerging trends of the real estate to investigate the industry transformations, targeting various real estates which include office buildings, logistics, data center, hotel, and residential buildings. This report includes data and insights form various research centers, news, consulting firms, real estate firms, governments, and financial institutions. While under thorough investigation, it is known that the pandemic has accelerated the transformations of real estate industry that enables itself to resist the industry recession, boost the industry development, and generate lots of investment opportunities in the industry as most of the real estate is currently undervalued that the investors could dig into to reap the benefits from the recovery of the reviving real estate industry.
\end{abstract}

Keywords: Real estate investments, real estate transformations, real estate emerging trends, real estate investors, real estate during pandemic, real estate development

\section{INTRODUCTION}

The pandemic has hit the real estate industry badly due to poor economy, reduced business and consumption activities that results from the border restrictions and social distancing. While how the real estate industry and the developers resist the industry recession intrigued me to investigate the transformations and the emerging trends of the industry to find out the investment opportunities in various real estate, including office buildings, logistics, data center, residential buildings, and hotel. This report is useful for predicting the emerging trends of the real estate industry development, ways of transforming the real estate to resist the industry recession, as well as giving investment insights to real estate investors.

\section{OFFICE BUILDINGS}

During COVID-19, with the purpose to strike a balance in maintaining operations of the company and reducing the infection risks, most of the companies have no choice but to adopt the 'work from home' policy. According to a survey from Pew Research Center [1], $71 \%$ of the respondents are currently working from home, around a $50 \%$ increase since COVID-19 (20\%). While it seems inconvenient at the first glance, but most of the workers are used to it and it becomes a norm that even $54 \%$ of them would like to work from home after the coronavirus ends due to greater flexibility and productivity. Therefore, a mixed mode of working from home and working in office would be prevalent in the post-COVID period and investors should look at the transformations of the office buildings for investment.

Companies now raise the requirements towards the office buildings in various parameters. Since companies in the office buildings now require less space to operate as people could work remotely, they would see this as a chance to downsize and reduce fixed costs by renting a smaller office for better space utilization. Thus, the demand for a central headquarter reduces, which decentralization is an emerging trend. A case study [2] is that the urban planning authorities in Singapore is now accelerating in decentralizing the Central Business District (CBD) by bringing workplaces closer to homes, and to attract companies moving out of $\mathrm{CBD}$, the government even relocating some ministries and statutory boards out of CBD. Thus, people are paying more and more attention to the satellite business centers, which is an ideal place for those non-client-facing 
business departments such as middle office and back office. At the same time, it is also closer to where people live, reducing workers' cost in transportation. Some companies may even use this as a strategy to attract talents as this favors the employees.

Moreover, since the pandemic outbreak, companies are paying more attention to the health and hygiene conditions of the office buildings, thus the demand for a virus-proof office buildings raise, such as a touchless system being adopted in elevators, office doors, and security gates which prevents the spread of the transmission diseases. Moreover, according to a report 'Future of offices: in a post-pandemic world' [3] by ARUP, it said 'As the economy recovers from COVID19 there will be greater demand for flexible buildings that can be easily adapted for new uses in the event of future market disruptions, driven by circular and resiliency principles. As sector lines blur, new business ecosystems emerge.' It could be seen that office buildings with flexible systems that allow a variety of companies to work in various modes becomes more and more valuable. A case in point is that there are more and more weworkstyle co-working spaces emerging in the market. Therefore, investors should pay attention to those office buildings which provide business flexibility and offers pandemic-resistant facilities at the same time.

In conclusion, the pandemic has changed the way how companies view the office buildings. The transformations in office buildings real estate includes focusing on decentralization, paying more attention to germ-resistant office as well as flexible co-working spaces. It is important for real estate investors to look at the transformations of office buildings before investing.

\section{LOGISTICS REAL ESTATE}

Logistics real estate refers to a hall area that is used for storage, order picking and goods distribution. While the pandemic hit the real estate industry severely, logistics real estate is the only one who still standalone and even have the best performance at a historical high level, according to a report from Real Capital Analytics [4], the APAC logistics investment volume reached $\$ 13.5$ billion in 2020, greater than that in 2019 and 2018, and even double that of 2017. While e-commerce has already been prevalent before the pandemic, the COVID outbreak and the social distancing even boost ecommerce to the next level, since e-commerce requires packaging individual deliveries and handling returned items, the need for logistics storage space surge to an unprecedented level, according to a report from CBRE [5], e-commerce in current logistics stock requires 2.4 times more logistics space than store-based retail. Thus, it increases demand for logistics real estate drastically and boosting supply chain investments.
While before the pandemic, manufacturers adopt lean logistics and Just-In-Time manufacturing to lower the inventory cost and for better space utilization. However, problems that are hidden in plain sight expose during the pandemic, during the COVID outbreak. Most of the factories halted the production and a shortage of inventories occur. A case in point is that shortage of semiconductor chips happened in Ford, General Motors, and Tesla, which slows down the production process. Thus, manufacturers are now increasing the buffer stock on hand, which prevents the shortage of inventories and maintains the production process. According to a survey from Gartner's Future of Supply Chain: Crisis Shapes the Profession report [6], 43\% of supply chain professionals are increasing the safety stock now while $11 \%$ of them are planning to do so within the next two years. Since keeping more inventories on hand requires more warehouses and storage space, it boosts the demand for logistics real estate.

While the pandemic also boosts the need for cold storage space, as the social distancing and the decline in dining-out options which push up the online grocery sales significantly, according to CBRE research [7], an additional of 75-100 million square feet of industrial freezer and cooler space are needed to meet the demand generated by online grocery sales in the next five years, which again increases the demand for larger warehouses with a higher capacity and boost the cold storage logistics real estate investment. While not only could cold storage space be used to store perishables like frozen meat, but it could also be used to store vaccine or drugs from pharmaceutical companies which are booming during the pandemic. While cold-storage logistics real estate has higher rental yields and longer leases since most of the warehouses do not have the high-quality equipment and temperature-controlled facilities that the perishables or vaccine require which are temperature-sensitive that it may denature with just a few fluctuations in temperature. Therefore, the cold storage logistics real estate could offer investors a high rate of returns that they should not miss the opportunity.

\section{DATA CENTER REAL ESTATE}

Since the pandemic increases the need for virtual meetings, e-learning, e-commerce, and remote working, it leads to a $47 \%$ increase in global internet traffic in 2020, according to a report from CBRE [8]. It increases the demand for the data storage and cloud computing services to a new high level, which creates a surge of demand in building more and more edge data centers. According to a report from pwc [9], the global market for edge data centers is expected to triple to $\$ 13.5$ billions in 2024 from \$4 billion in 2017.

Traditionally, companies would have their core data centers real estate concentrated in tier one markets, such as those capital cities like Tokyo and Sydney, thus it 
creates the demand for the edge data centers especially in tier two or tier three markets, such as those remote areas around the capital cities, as user catchments might be far away from the connectivity hubs. A case in point is that Cisco and Leading Edge Data Centers collaborate to bring edge data centers to regional Australia such as Victoria and Queensland, according to Datacenter News [10].

While the construction of more and more edge data centers is inevitable, since $5 \mathrm{G}$ has already been implementing which raise the needs for high bandwidth networking infrastructure, according to ReportLinker [11], China Mobile, China Telecom and China Unicom have built over 700,000 edge data centers and are planning to add 600,000 in 2021 for the implementation of $5 \mathrm{G}$ network. While the emerging smart city development will also boost the demand for edge data centers to support a highly decentralized network.

Since the market of data center real estate is booming, it attracts many investors for investment due to the huge demand for data storage and cloud computing. According to CBRE's 2021 Asia Pacific Investor Intentions Survey [12], investors have the strongest interest in data centers among all types of alternative real estate. It reveals the data center real estate is having a bright future that investors should not miss to luring a profit.

\section{RESIDENTIAL REAL ESTATE}

The pandemic hit the residential real estate badly that the housing price keeps dropping and dropping. While with the introduction of vaccine, the pandemic is getting controlled gradually, the housing prices seem to have a rebound. While the situation varies in different regions, different investment opportunities appear.

While Hong Kong's residential property is well known for its most expensive housing price in the world, and it keeps increasing. Under the pandemic, the rocketing housing price slows down its pace and becomes relatively stable, according to Rating and Valuation Departments (RVD) [13], Hong Kong's residential property index was unchanged in 2020. Despite the housing price is keeping stable, the demand of residential property drops, as according to RVD, the number of property transactions decreased by $4.9 \%$ in 2020. However, the construction completions surged $32.9 \%$ in 2020 , although the demand drops under pandemic, it is still far greater than supply that there are huge shortages of housing in Hong Kong that it makes the housing price relatively stable even under the pandemic. It is foreseeable that when the pandemic is over, the housing price would rocket again that there are lots of residential real estate investment opportunities in Hong Kong.
While there are many property investment opportunities in emerging markets like Vietnam. According to JLL Vietnam [14], the housing prices increase $27.5 \%$ in 2020, showing a very strong performance in property real estate. The rocketing housing price is due to the shortage of housing supply that the developers have a greater bargaining power over the buyers that they could raise the price of the property under the slow growing economy due to the pandemic. Owing to the huge demand for property real estate, according to JLL, supply rise drastically with an additional 3820 units launched, doubling the amount in the first quarter of 2020.

Moreover, it is more than above-mentioned that makes Vietnam a hotspot for property investment. The GDP growth rate for Vietnam is around 7\% in 2019, according to The World Bank [15], showing a booming economy. It can be reflected in its unemployment rate, which decreases from $2.13 \%$ in 2015 to $2.01 \%$ in 2019 , showing a decreasing trend, according to macrotrends [16]. It is because there are rocketing job opportunities in logistics and manufacturing industries as Vietnam would like to expand its export-driven economy. It is even fueled by China plus one strategy due to the US-China trade war that many companies are diversifying their supply chains, which relocates their factories to Vietnam. These all boost the economy of Vietnam. With a better and better economy, the population of Vietnam is growing steadily, according to The World Bank [17], the population growth of Vietnam is around 1\%, this again raising the demand for the housing property. While Vietnam is a place where foreign investment is easy due to the government policy, the government allows foreigners to purchase $30 \%$ at maximum of a residential project, which attracts lots of foreign investors for property investment. According to a report from DataSpeaks [18], foreigners own 16,000 units in Vietnam, which accounts for $2 \%$ of the total housing supply. While the rental yields in Vietnam are relatively good, according to GPG [19], the rental yield is around $4 \%$ to $7 \%$ in Hanoi, the capital city of Vietnam. All in all, Vietnam is an emerging market that many investors have been digging in to lure a profit.

\section{HOTEL REAL ESTATE}

The pandemic hit the hotel real estate badly as the travel restrictions and lockdowns prohibit all kinds of traveling, but with the introduction of vaccines and the relaxation of border restrictions, the hotel real estate is reviving, and many investors have already made an investment in hotel real estate to lure the profits of industry's recovery. According to a report from JLL [20], the global hotel investment volume would have a rise of 35 to $40 \%$ compared to that in 2020. For example, Blackstone, a top private equity firm, bought eight hotels in Japan from Kintetsu Group Holdings, a well-known 
Japanese Conglomerate in real estate. Another example is that Alta Capital Real Estate in Hong Kong has set up a fund - Alta Hospitality Fund Asia, which consists of US $\$ 50$ million, with an expected return of 15 to $25 \%$ over six years, targets to invest in undervalued hospitality assets across the Asia Pacific, according to Travel Daily News [21]. It could be seen that investors do have the confidence that hotel real estate is recovering that it is worth their investment, given that the pandemic is being contained and the border is gradually opening with the increasing vaccination rate.

\section{CONCLUSION}

All in all, although the pandemic hit the real estate industry severely, it catalyzes the transformations of the real estate industry, which enables itself to overcome the industry recession in the period of COVID, boost the industry growth, and at the same time provide a variety of investment opportunities in different types of real estates, ranging from office buildings, logistics real estate, data center, residential and hotel real estate, as the real estate industry is reviving since the economy is getting better and everything is getting back on the right track. Therefore, investors could dig into the undervalued real estate industry to reap the benefits of the industry's recovery and this report could give some investment insights to real estate investors.

\section{ACKNOWLEDGMENT}

I would like to give my deep and sincere gratitude to my professors, parents, classmates, and friends, who always support me from behind when I was struggling in writing the essay. Their emotional support really matters to me and that helps me a lot. From frequent conversations with them, I always have some fresh insights and new ideas in writing the essays, so hereby I would like to appreciate their contributions in my essay.

Moreover, I would also like to give credits to research centers, news, consulting firms, real estate firms, governments, and financial institutions that listed in references for their data and insights. Their data and statistics, as evidence, are significant in proving my insights and ideas, so here I would like to give a special thanks to them.

\section{REFERENCES}

[1] Kim Parker, Juliana Menasce Horowitz, Rachael Minkin; How the Coronavirus Outbreak Has - and Hasn't - Changed the Way Americans Work; Pew Research Center; 2020
[2] Karamjit Singh; Acceleration towards a decentralized CBD as remote working takes hold; The Straits Times; 2020

[3] James Finestone, James Ward, Marcus Morrell, Neil Rebeugeot, Paula Walsh, Rebecca Goldberg, Stu Manton, Tristan More; Future of offices in a post pandemic world; ARUP; 2020; 52

[4] Christopher Caillavet; APAC Logistics Investment Volume Reached Record \$13.5B In 2020; Mingtiandi; 2021

[5] Igor Petkovic, Hampus Otterhall, Jenna Hayrynen, Daniel Marthendal; The e-commerce effect on logistics' real estate; CBRE Research; 2020

[6] Matt Leonard; Supply chains divided on plans to increase safety stock, stick with lean methods; Supply Chain Dive; 2021

[7] Coronavirus Will Increase Demand for Cold Storage Options; CBRE Research; 2020

[8] Asia Pacific Data Centre Trends H2 2020; CBRE Research; 2021; 3

[9] Edge data centers: Riding the $5 \mathrm{G}$ and IoT wave; PwC; 2019; 2

[10] Cisco and LEDC collaborate to bring data centers to regional Australia; Datacenter News Asia; 2020

[11] The China and Hong Kong data center market by investment is expected to grow at a CAGR of approx. 4\% during the period 2020 - 2026; ReportLinker; 2021

[12] Asia Pacific Investor Intention Survey 2021; CBRE Research; 2021; 12

[13] Residential Property Index; Rating and Valuation Department; 2020

[14] Vietnam Market Property Overview 2Q20; JLL; 2020; 7

[15] GDP growth (annual \%) - Vietnam; The World Bank; 2020

[16] Vietnam Unemployment Rate 1991 - 2021; Macrotrends; 2021

[17] Population growth (annual \%) - Vietnam; The World Bank; 2020

[18] Dat Nguyen; Foreigners own 2 pct of Vietnam housing supply; VnExpress International; 2020

[19] Lalaine C. Delmendo; Vietnam's property market remains resilient; Global Property Guide; 2020 
[20] Graldine Guichardo, Jessica Jahns, Ophelia Makis, Sze-min Tay; Hotel Investment Outlook 2021; JLL; $2021 ; 5$

[21] Theodore Koumelis; Alta Capital Real Estate launches new fund targeting hospitality developments focused on sustainability and wellness; Travel Daily News Asia; 2020 